І. М. Кліщ, М. І. Марущак, І. Я. Криницька, Г. Г. Габор ДВНЗ “Тернопільський державний медичний університет імені I. Я. Горбачевського МОЗ України”

\title{
ОСОБЛИВОСТІ ВПРОВАДЖЕННЯ ПРОЦЕСУ КОМЕРЦІАЛІЗАЦІЇ РЕЗУЛЬТАТІВ НАУКОВИХ ДОСЛІДЖЕНЬ У ЗАКЛАДАХ ВИЩОЇ МЕДИЧНОЇ ОСВІТИ
}

\author{
I. M. Klishch, M. I. Marushchak, I. Y. Krynytska, H. H. Habor \\ I. Horbachevsky Ternopil State Medical University

\section{FEATURES OF IMPLEMENTATION OF THE SCIENTIFIC RESEARCHES RESULTS COMMERCIALIZATION IN THE HIGHER EDUCATION} \\ MEDICAL INSTITUTIONS
}

\begin{abstract}
Мета роботи - аналіз можливих заходів з комерціалізації об’єктів інтелектуальної власності у закладах вищої медичної освіти Основна частина. В Україні практика активного залучення об’єктів інтелектуальної власності сьогодні перебуває на стадії становлення, тому в даній статті ми розглянули шляхи залучення науково-педагогічного складу медичних навчальних закладів у процеси комерціалізації об’єктів інтелектуальної власності.

Комерціалізація технологій є важливим елементом інноваційного процесу та сталого розвитку університетів, оскільки являє собою процес перетворення результатів наукової діяльності на продукт і можливість отримання додаткового прибутку або іншої вигоди.

Висновок. Для успішної комерціалізації наукових розробок із метою забезпечення сталого розвитку закладів вищої медичної освіти необхідно мотивувати науково-педагогічний склад до створення інноваційних розробок, забезпечувати фінансову підтримку на стадії поширення інформації, а також сформувати підрозділ з комерціалізації об’єктів права інтелектуальної власності для підтримки науковців на стадії впровадження.
\end{abstract}

Ключові слова: комерціалізація; заклади вищої медичної освіти.

The aim of the work - to analyze possible ways for the commercialization of intellectual property objects in higher medical education institutions.

The main body. In Ukraine, the practice of active involvement of intellectual property objects is at the stage of formation, therefore, in this article we have considered ways of attracting the scientific and pedagogical composition of medical educational institutions in the process of commercialization of intellectual property objects.

Commercialization of technologies is an important element of the innovation process and the sustainable development of universities, as it represents the process of transforming the results of scientific activity into a product and the possibility of obtaining additional profit or other benefit.

Conclusion. For successful commercialization of scientific products in order to ensure the sustainable development of higher medical education institutions, it is necessary to motivate the scientific and pedagogical staff to create innovative developments, to provide financial support at the stage of dissemination of information, and to form a unit for the commercialization of intellectual property objects to support scientists at the stage implementation.

Key words: commercialization; higher medical education institutions.

Вступ. Сучасний етап розвитку світової промисловості, у тому числі і медичної, характеризується зростанням ролі інформації і знань, які стають основним фактором економічного зростання держави [1]. Практика показує, що тільки за умови розвитку інноваційним шляхом забезпечуються стійкі конкурентні переваги підприємств й освіт-

(c) I. М. Кліщ, М. І. Марущак, І. Я. Криницька, Г. Г. Габор ніх закладів. Проблема прискорення інноваційного розвитку нашої країни нероздільно пов'язана 3 проблемою комерціалізації результатів науководослідної діяльності, що виступає одним з основних стимулюючих чинників збільшення прибутків підприємств, завоювання більш місткого сегмента ринку, а також примноження національного багатства та підвищення рівня інноваційної безпеки 
України [2]. Слід зазначити, що європейські країни інвестують значні кошти в розвиток науки та освіти, які продукують і поширюють нові знання для розробки нових продуктів, технологій, методів управління тощо. В Україні за останнє десятиріччя інтелектуальна власність набуває характеру стратегічного потенціалу кожного підприємства, організації чи установи, комерціалізація якої дозволить підвищити конкурентоспроможність за рахунок введення в обіг накопиченого науково-технічного потенціалу, нових технологій і знань. Проблеми комерціалізації досліджено в роботах багатьох вітчизняних і зарубіжних науковців, таких, як Р. Бендерієн, Г. Л. Ступнікер, Н. П. Мешко, П. В. Робота, В. А. Денисюк, Е. П. Маккой, Г. І. Жиц, М. Н. Квашніна, Р. Бадінелі, К. Т. Коебель, В. Табет [3]. В Україні практика активного залучення об'єктів інтелектуальної власності сьогодні перебуває на стадії становлення, тому в даній статті ми розглянули шляхи залучення науково-педагогічного складу медичних навчальних закладів у процеси комерціалізації об’єктів інтелектуальної власності.

Мета роботи - аналіз можливих заходів з комерціалізації об'єктів інтелектуальної власності у закладах вищої медичної освіти.

Основна частина. Із трансформацією суспільства, відповідно до сучасних потреб, особливої значущості набувають нематеріальні складові успішної роботи закладу вищої освіти (ЗВО), які являють собою інтелектуальну власність, інтелектуальний капітал, інтелектуальні ресурси та інтелектуальний потенціал установи [4]. У кожному 3ВО виконуються науково-дослідні роботи з метою забезпечення змісту і форм наукової, навчальної, творчої та виховної діяльності; безперервного підвищення компетентності і професійної майстерності кожного викладача; участі в роботі із впровадження в освітній процес інноваційних педагогічних та інформаційних технологій [5]. Результатами наукової діяльності є об’єкти інтелектуальної власності: друковані праці, дисертації, патенти, авторські свідоцтва. Здатність перетворення об’єктів інтелектуальної власності на товар та на капітал є основою їх комерціалізації, що слугує ефективним інструментарієм для збільшення прибутків та можливостей науково-педагогічних закладів, а також підвищує їх конкурентоспроможність.

Комерціалізація результатів наукових досліджень - це відповідальний етап роботи з результатами наукової розробки, котра пройшла капіталізацію й визначена об'єктом інтелектуальної власності, на який одержано охоронні документи і який має специфічні ознаки, що дає можливість розглядати його як інноваційний товар, який відповідає умовам ринку [6]. Проте виникає питання, чи результати науково-дослідних робіт є інтелектуальним капіталом з комерційним потенціалом? I відповідь тут неоднозначна. Найчастіше результати українських дослідників і науковців залишаються виключно паперовими результатами, які не мають достатньої наукової цінності і лише піднімають на поверхню тематики, які прогресивні вчені світу підхоплюють та розвивають у великі і грандіозні проекти, які в майбутньому принесуть прибуток. Практично завжди український дослідник чи науковець проявляє максимальну активність на першій стадії створення інноваційних розробок, яка включає проведення фундаментальних та прикладних наукових досліджень, не досягаючи кінцевої стадії - розробки інноваційної продукції. Велике значення у створенні інноваційних об'єктів інтелектуальної власності у медицині мають заходи на шляху до комерціалізації та трансферу наукових розробок, зокрема презентація наукової продукції на ярмарках, симпозіумах, конференціях як державного, так і світового рівнів. При цьому такі заходи дають можливість ознайомитися зі здобутками інших наукових установ, виявити конкурентів та залучити колег до вигідної співпраці. Проблемою поширення інформації про об'єкти інтелектуальної власності $\epsilon$ необхідність фінансування таких заходів. Як один із шляхів вирішення фінансових питань під час комерціалізації наукових розробок $€$ інтеграція вищої освіти, науки та бізнесу. Зростання інтересу комерційних підприємств до наукомістких продуктів і технологій робить можливим комерційне використання результатів наукових розробок науково-педагогічного складу 3ВО, підвищує ймовірність залучення капіталу комерційних структур із метою створення університетом власного виробництва або ж використання інноваційних розробок у роботі комерційних підприємств. Аналіз ресурсів internet свідчить про те, що уряди багатьох зарубіжних країн стимулюють установлення більш тісних зв'язків між фірмами високотехнологічних галузей і державними дослідницькими університетами для того, щоб створювати центри нових технологій. Так, в Америці існують так звані “науково-технологічні парки”, які $є$ інкубаторами наукомісткого бізнесу і практичною основою наукової діяльності університетів. У Польщі, як і в багатьох країнах Європейського Союзу, державне стимулювання діяльності науково-дослідних 
інститутів, вчених відбувається шляхом розвитку системи кластерних наукових об’єднань, системи технопарків. Практично в кожному університеті $є$ наукові парки, які надають допомогу досліднику чи науковцю у втіленні їх ідеї у конкретний продукт. У Німеччині та Австралії інтеграція державної науково-технічної політики з державною промисловою політикою відбувається за рахунок державної підтримки обміну персоналом, розвитку державно-приватних партнерств [7, 8]. На думку уряду України, ЗВО повинні самі прагнути комерціалізувати результати своїх наукових досліджень, хоча ефективність комерціалізації лише частково залежить від самих 3ВО, які, безумовно, повинні стимулювати інноваційну діяльність науковців, підвищувати вимоги до результативності виконання науково-дослідних робіт, створювати відповідну інфраструктуру [9].

Для реалізації ефективної політики комерціалізації інтелектуальної власності від ідеї до готового продукту ми рекомендуємо в ЗВО створити в складі наукового відділу підрозділ з комерціалізації об’єктів права інтелектуальної власності, де ввести фахівців по менеджменту та юриспруденції, підготовлених до здійснення комплексу завдань 3 комерціалізації результатів наукових досліджень.

\section{Список літератури}

1. Піддубна Л. В. Інформація як складова економічного розвитку суспільства / Л. В. Піддубна // Зовнішня торгівля: право, економіка, фінанси. - 2012. - № 3. С. $122-131$.

2. Шматенко Р. М. Комерціалізація результатів наукових досліджень аграрних наукових установ [Електронний ресурс] / Р. М. Шматенко. - Режим доступу : http:// intkonf.org/shmatenko-rm-komertsializatsiya-rezultativnaukovih-doslidzhen-agrarnih-naukovih-ustanov/.

3. Ілляшенко С. М. Теоретико-методичні засади вибору напрямів комерціалізації знань на промислових підприємствах / С. М. Ілляшенко, Є. В. Рот-Сєров // Науковий вісник Мукачівського державного університету. - 2017. - С. 86-93.

4. Шушакова I. К. Особливості комерціалізації об’єктів інтелектуальної власності на вітчизняних підприємствах / I. К. Шушакова // Фінансово-кредитна діяльність: проблеми теорії та практики. - 2015. - Т. 2, № 19. - C. 133-141. DOI: http://dx.doi.org/10.18371/ fcaptp.v2i19.56922.

5. Карпенко М. Проблеми розвитку університету науки в Україні в контексті європейського досвіду [Електрон-
Для забезпечення умов інноваційного зростання університету необхідно підвищувати кваліфікацію працюючих співробітників на науково-практичних семінарах з вивчення питань правової охорони інтелектуальної власності, набуття та захисту прав на об’єкти інтелектуальної власності, комерціалізації об’єктів інтелектуальної власності.

Отже, комерціалізація технологій є важливим елементом інноваційного процесу та сталого розвитку університетів, оскільки являє собою процес перетворення результатів наукової діяльності на продукт і можливість отримання додаткового прибутку або іншої вигоди. Створення об’єктів інтелектуальної власності передбачає наявність в учасників перспективного мислення, необхідної мотивації, технічних можливостей, наукового потенціалу та фінансових ресурсів [10].

Висновок. Для успішної комерціалізації наукових розробок із метою забезпечення сталого розвитку закладів вищої медичної освіти необхідно мотивувати науково-педагогічний склад до створення інноваційних розробок, забезпечувати фінансову підтримку на стадії поширення інформації, а також сформувати підрозділ з комерціалізації об’ єктів права інтелектуальної власності для підтримки науковців на стадії впровадження.

ний ресурс] / М. Карпенко. - Режим доступу : http:// old. niss.gov.ua/Monitor/june2009/22.htm\#_ftn2.

6. Володін С. А. Інноваційний розвиток аграрної науки : монографія / С. А. Володін. - К. : МАУП, 2006. 400 с. : іл.

7. Прохоров А. Н. Зарубежный опыт построения процесса коммерциализации интеллектуальной собственности / А. Н. Прохоров // Вестник Тюменского гос. ун-та. - 2011. - № 11. - С. 66-70.

8. Офіційний сайт Державної служби інтелектуальної власності України [Електронний ресурс]. - Режим доступу : http://sips.gov.ua/ua/plans_reports.html.

9. Меняйло В. Комерціалізація результатів наукових досліджень вищих навчальних закладів України як пріоритет державної політики у сфері вищої освіти / В. Меняйло // Вісник Національної академії державного управління. - 2012. - № 4. - С. 130-137.

10. Фоміна Є. В. Комерціалізація наукових розробок як основний елемент інноваційної економіки / Є. В. Фоміна // Вісник Харківського Національного університету імені В. Н. Каразіна. - 2017. - С. 124-128. 


\section{References}

1. Piddubna, L.V. (2012). Informatsiia yak skladova ekonomichnoho rozvytku suspilstva [Information as a component of the economic development of society]. Zovnishnia torhivlia: pravo, ekonomika, finansy - Foreign trade: law, economics, finance, 3, 122-131 [in Ukrainian].

2. Shmatenko, R.M. (2018). Komertsializatsiia rezultativ naukovykh doslidzhen ahrarnykh naukovykh ustanov [Commercialization of results of scientific researches of agrarian scientific institutions]. Retrieved from: http:// intkonf.org/shmatenko-rm-komertsializatsiya-rezultativnaukovih-doslidzhen-agrarnih-naukovih-ustanov/ [in Ukrainian].

3. Illyishenko, S.M. (2017). Teoretyko-metodychni zasady vyboru napriamiv komertsializatsii znan na promyslovykh pidpriemstvakh [Theoretical and methodical principles of choosing the areas of commercialization of knowledge at industrial enterprises]. Naukovyi visnyk Mukachivskoho derzhavnoho universytetu - Scientific Bulletin of Mukachevo State University, 86-93 [in Ukrainian].

4. Shushakova, I.K. (2015). Osoblyvosti komertsializatsii obiektiv intelektualnoi vlasnosti na vitchyznianykh pidpriemstvakh [Peculiarities of commercialization of intellectual property objects at domestic enterprises]. Finansovo-kredytna diialnist: problemy teorii ta praktykyFinancial and Credit Activity: Problems of Theory and Practice, 2 (19), 133-141 [in Ukrainian].

5. Karpenko, M. (2009). Problemy rozvytku universytetu nauky v Ukraini v konteksti yevropeyskoho dosvidu [Problems of the University of Science in Ukraine in the context of European experience]. Retrieved from: http:// old. niss.gov.ua/Monitor/june2009/22.htm\#_ftn2. [in Ukrainian]. 6. Volodin, S.A. (2006). Innovatsiynyi rozvytok ahrarnoi nauky [Innovative development of agrarian science]. Kyiv: MAUP [in Ukrainian].

7. Prokhorov, A.N. (2011). Zarubezhnyy opyt postroyeniya protsessa kommertsializatsii intellektualnoy sobstvennosty [Foreign experience in constructing the process of commercialization of intellectual property]. Vestnik Tyumenskogo gos. un-ta - Bulletin of the Tyumen State University, 11, 66-70 [in Russian].

8. Ofitsiynyi sait Derzhavnoi sluzhby intelektualnoi vlasnosti Ukrainy [Official site of the State Service of Intellectual Property of Ukraine]. Retrieved from: http:// sips.gov.ua/ua/plans_reports.html [in Ukrainian].

9. Meniailo, V. (2012). Komertsializatsiia rezultativ naukovykh doslidzhen vyshchykh navchalnykh zakladiv Ukrainy yak priorytet derzhavnoi polityky u sferi vyshchoi osvity [Commercialization of results of scientific researches of higher educational institutions of Ukraine as a priority of state policy in the field of higher education]. Visnyk Natsionalnoi akademii derzhavnoho upravlinnia - Bulletin of the National Academy of Public Administration, 4, 130137 [in Ukrainian].

10. Fomina, Y.V. (2017). Komertsializatsiia naukovykh rozrobok yak osnovnyi element innovatsiinoi ekonomiky [Commercialization of scientific developments as the main element of the innovation economy]. Visnyk Kharkivskoho Natsionalnoho universytetu imeni V.N. Karazina - Karazin Bulletin of Kharkiv National University, 124-128 [in Ukrainian].

Отримано 03.08.18

Електронна адреса для листування: marushchak@tdmu.edu.ua 